\title{
Comparison of Heavy Metal Levels of Organic and Conventional Milk and Milk Products in Turkey
}

\author{
Mansur Seymen Seğmenoğlu ${ }^{1, a, *}$, Emine Baydan ${ }^{2, b}$ \\ ${ }^{1}$ Department of Nursing, Faculty of Health Sciences, Osmaniye Korkut Ata University, 80000 Osmaniye, Turkey. \\ ${ }^{2}$ Department of Pharmacology and Toxicology, Faculty of Veterinary Medicine, Ankara University, 06100 Ankara, Turkey.
} *Corresponding author

\begin{tabular}{l|l}
\hline A R T I C L E I N F O & A B S T R A C T \\
\hline $\begin{array}{l}\text { Research Article } \\
\text { Received : 20/10/2020 }\end{array}$ & $\begin{array}{l}\text { This study aimed to determine and compare aluminum (Al), arsenic (As), cadmium (Cd), and lead } \\
\text { (Pb) levels in conventional and organic milk, white cheese, and butter samples which are sold in } \\
\text { the markets of Turkey. Within the scope of the study, totally } 72 \text { samples (36 for organic, and 36 for } \\
\text { conventional) were collected, and analyzed between March } 2010 \text { and February 2011. After the } \\
\text { samples were burned by microwave burning, element measurements were performed on atomic } \\
\text { absorption spectrophotometer (AAS) device. As a result of the study, on the 49 samples (29 } \\
\text { conventional, } 20 \text { organic) of the } 72 \text { collected product, element levels were determined above the } \\
\text { limit of detection (LOD) (0.02 ppm). Pb and Al were the most common elements above the LOD. } \\
\text { However, milk samples with a Pb level above the LOD still remained below the limit reported by } \\
\text { the Turkish Food Codex Regulation for Contaminants. Since Turkish Food Codex Regulation does } \\
\text { not have legal limits for Al, As, Cd and Pb for dairy products (cheese and butter), it was accepted } \\
\text { as safe in terms of Al, As, Cd and Pb according to food limits in Turkish Food Codex and ADI } \\
\text { values of FAO / WHO. }\end{array}$ \\
$\begin{array}{l}\text { Keywords: } \\
\text { Dairy product } \\
\text { Metal level }\end{array}$ &
\end{tabular}

Organic milk

Contaminants

mansurseymen@gmail.com

(iD http://orcid.org/0000-0003-2743-6245

baydan@veterinary.ankara.edu.tr

http://orcid.org/0000-0001-5459-8616

(c) (1) () To This work is licensed under Creative Commons Attribution 4.0 International License

\section{Introduction}

The United States (USA), Canada, Austria, Denmark, Germany, England, France, and Argentina are the leading countries in organic livestock production. In the USA, organic dairy products have a share of $2 \%$ in total milk production. EU countries Austria and Denmark take the first place in the production of organic milk with 300 tons/year production. In Turkey, almost all of the organic food production consists of herbal products. Apart from organic honey production, the production quantity of organic milk, dairy products, and other animal products is a little (Çiçek and Tandoğan, 2009).

The use of tools and equipment that are not in compliance with the standard in the production of dairy products and the closeness of their production facilities to the industrial establishments are significant in the exposure of milk and cheese samples to heavy metal contamination (Temurci and Güner, 2006). Heavy metals that have no vital importance such as aluminum (Al), arsenic (As), cadmium $(\mathrm{Cd})$, lead $(\mathrm{Pb})$, etc., even in very low concentrations, can affect the physiological structure and cause health problems (Gövercin, 2010). The International Agency for Research on Cancer (IARC) classified substances such as arsenic, cadmium, and inorganic lead compounds as carcinogens (IARC, 1993).

Organic farming avoids using synthetic chemicals, hormones, antibiotic agents, genetic engineering, and irradiation (Forman and Silverstein, 2012). However, sometimes organic products may contain some contaminants (Baydan et al., 2017). There has been little research on the safety of organic foods, especially organic animal products. There are some studies on the determination of pollutants such as heavy metal, pesticide and mycotoxin in organic products (Malmuret et al., 2002; Wang et al., 2003). Yet, there is only one research conducted to determine heavy metal levels in some organic products (wheat, lentils, flowers honey, and eggs) in Turkey (Arslanbaş and Baydan, 2013). Therefore, the aim of this research was to determine some heavy metal (Al, 
$\mathrm{As}, \mathrm{Cd}$, and $\mathrm{Pb}$ ) levels in conventional and organic dairy products offered for sale in Turkey and compare the results with national and international studies.

\section{Materials and Methods}

In this study, 36 organic and 36 conventional samples with different serial/batch numbers, consisting of milk, cheese and butter were sold in markets of Turkey were collected; 3 samples for each kind of product ( 9 for organic, and 9 for conventional) in every three months period between March 2010 and February 2011. Organic samples were belonging to a single company due to lack of other company's products are sold in markets in Turkey on the dates indicated. Conventional samples belonged to different companies. The collected samples were stored in the freezer $\left(-20^{\circ} \mathrm{C}\right)$ until analyzed. Samples were analyzed for their $\mathrm{Al}, \mathrm{As}, \mathrm{Cd}$ and $\mathrm{Pb}$ content and level, if any.

Metal levels of the extracts obtained after burning $2 \mathrm{ml}$ milk, $0.5 \mathrm{~g}$ white cheese, and $0.5 \mathrm{~g}$ butter samples in microwave oven (Berghof MWS-2, Germany) were detected according to parameters in Table 1 in the AASGraphite device (Perkin Elmer Analyst 700, Graphite Furnace, USA) (Çakır, 2009).

Frozen milk, white cheese, and butter samples were thoroughly dissolved in the analysis stage. Dissolved samples were weighed and put into teflon containers separately in the quantities of $2 \mathrm{ml}$ for milk samples and $0.5 \mathrm{~g}$ for cheese and butter samples. The samples were mixed well by adding $3 \mathrm{ml}$ of $\mathrm{HNO}_{3}(65 \%)$ and $1 \mathrm{ml} \mathrm{H}_{2} \mathrm{O}_{2}$ (30\%). After about 20 minutes, the lids of the Teflon containers were closed and placed in a microwave oven. At the end of the burning process, the extract was added deionized water and brought to the level that can be analyzed in AAS device with the element's parameters in Table 2. $\mathrm{Al}, \mathrm{Cd}$, and $\mathrm{Pb}$ levels of the samples were measured in a graphite furnace unit. The As level was measured as the analyte hydrides (arsenic hydride) after making hydrolysis with $\mathrm{NaBH}_{4}$ (sodium borohydride) in acidic solution with sending it into the quartz tube heated by flame (or electricity) by means of inert gas.

Statistical analysis of the data obtained at the end of the study was done by the statistical package program (SPSS 15.0). In this context, the median, the minimum, and the maximum values were determined. Group comparisons were made with Mann-Whitney $U$ test for the groups with sample quantity 3 or higher. The level of significance was set at $\mathrm{P}<0.05$.

\section{Results and Discussion}

$\mathrm{Al}, \mathrm{As}, \mathrm{Cd}$, and $\mathrm{Pb}$ levels (median, min-max) of the 72 conventional and organic milk, white cheese, and butter samples analyzed were given in Table 3 . The LOD values in the AAS-Graphite device are for $\mathrm{Al}$ was $0.02 \mathrm{ppb}$, for as $0.001 \mathrm{ppb}$, for $\mathrm{Cd} 0.001 \mathrm{ppb}$, for $\mathrm{Pb} 0.02 \mathrm{ppb}$. Values below the LOD were accepted as zero and evaluated as missing observation in statistical analyzes. Al (10 ppb), As (2.5 $\mathrm{ppb}), \mathrm{Cd}$ (3 ppb), and $\mathrm{Pb}$ (10 ppb) were used for recovery studies. Recovery percentages by products and by metal sequence were; $99.4,99.9,102.6$, and 87.9 for milk (n: 1); $94.3,100.7,82.8$, and 101.6 for white cheese (n: 1); 84, 97.6, 109.9, and 72.9 for butter (n: 1).
As a result of the analyzes, there was no sufficient sample number above the LOD value, so statistical evaluation in terms of products and seasons could not be made (Figures 1 and 2).

According to the results of the study, 49 of the 72 samples were identified elements $(\mathrm{Al}, \mathrm{As}, \mathrm{Cd}, \mathrm{Pb})$ with values above the LOD levels. The frequency of elements with values above the LOD was higher in the conventional (29 conventional samples > LOD) than the organics group (20 organic samples > LOD), and among the sample groups, in the white cheese group (n: 17) (Figure 1). It was followed by conventional milk, organic white cheese, organic milk, and organic butter. In terms of incidence of metals, $\mathrm{Pb}$ was the first in all samples and $\mathrm{Al}$ was the second (Figure 1). In terms of $\mathrm{Pb}$ values, the difference between conventional and organic milk and white cheese groups was not statistically significant $(\mathrm{P}>0.05)$. It was observed that the frequency of $\mathrm{Pb}$ was increased in the samples collected in winter (Figure 2).

In Turkey and the world, although there are a limited number of studies to determine levels of elements in organic milk and dairy products, especially there are many studies for determining the elemental level of conventional milk samples. But organic products should also be screened for safety (Baydan et al., 2017). In a study on comparing element levels of conventional and organic dairy products in Southern Poland, there was no significant difference between organic and traditional products. Moreover, the presence of lead was detected in one of the organic milks $(5.24 \mathrm{mg} / \mathrm{l})$, and it was stated to be within acceptable limits (Halagarda et al., 2018). The results of this study showed that element levels in organic and conventional dairy products (cheese and butter) were higher than milk samples but below ADI values (Figure 1). Banks (1981) has been described cheese production as a process of condensing milk components, especially fat and protein contents (Abd El-Gawad and Ahmed, 2011). As in this study, elemental levels of condensed products such as white cheese and butter can be expected to be higher than milk samples. Indeed, Eleboudy et al. (2017) found that $\mathrm{Pb}$ and $\mathrm{Cd}$ values in condensed milk, evaporated milk and infant formula were significantly higher than milk values in their study. This is probably because they are condensed and evaporated products. In addition, higher element frequency and level in conventional and organic dairy products than milk samples may be associated, in addition to the causes of contagion in milk, with the contamination in the processing/storage/maturation conditions (container, packaging) in these stages (İnci et al., 2017; Shahria et al., 2014; Ziarati et al., 2018). In the study conducted by AIAshmawy (2011), Al levels in processed cheese wrapped in $\mathrm{Al}$ foil were significantly higher than those found in samples packed in glass containers. In a study on determination of levels of heavy metals (arsenic, lead, cadmium and mercury) in tin milk produced in Ghana, results of research have been indicated milk samples contamination by some heavy metals residues $(\mathrm{Hg}, \mathrm{Pb}, \mathrm{As}$ and Cd) (Amponsah, 2014). The results of research on milk and dairy products show that the element values of the products such as butter, cheese or condensed and evaporated milk are higher than milk samples and therefore different limits should be applied to dairy products provided that they do not exceed the ADI value. 
According to the Turkish Food Codex Regulation for Contaminants, the limit values of the elements likely to be present in foods are given as $15 \mathrm{mg} / \mathrm{kg}$ for $\mathrm{Al}, 0.1-1 \mathrm{mg} / \mathrm{kg}$ for As, $0.01-1 \mathrm{mg} / \mathrm{kg}$ for $\mathrm{Cd}$, and $0.02 \mathrm{mg} / \mathrm{kg}$ for $\mathrm{Pb}$ in milk (Anon, 2011). On the 49 samples (29 conventional, 20 organic) of the 72 , element levels were determined above the limit of detection (LOD) $(0.02 \mathrm{ppm}) . \mathrm{Pb}$ and $\mathrm{Al}$ were the most common and above the LOD level elements in the samples. However, milk samples that have $\mathrm{Pb}$ level above LOD were below the reported limit by the Turkish Food Codex Regulation for Contaminants. Since there are no legal limits for $\mathrm{Al}, \mathrm{As}, \mathrm{Cd}$ and $\mathrm{Pb}$ in dairy products, dairy products with elemental levels above LOD were considered safe for $\mathrm{Al}, \mathrm{As}, \mathrm{Cd}$ and $\mathrm{Pb}$ according to food limits in Turkish Food Codex Regulation. According to FAO/WHO, acceptable daily intake of $\mathrm{Pb}, \mathrm{Cd}$, and $\mathrm{Al}$ (ADI; $\mu \mathrm{g} / 70 \mathrm{~kg}$ person) were given as 500,70 , and 1200 , respectively (Abd-El Aal et al., 2012). Considering that an adult can consume $200 \mathrm{ml}$ of milk per day (Abd-El Aal et al., 2012), Al, As, Cd and Pb levels in milk samples are below ADI values. Since the ADI for cheese and butter was not stated, the evaluation could not be made regarding them. However, Turkey's Health Ministry Nutrition Guide 2015 (TÜBER) by approximately 40-60 grams a serving of cheese. Therefore, even if an adult consumes 3 servings a day, it was well below the limits given by FAO / WHO for Al, Cd and Pb (Abd-El Aal et al., 2012; Anon, 2016).

Table 1. Element reading parameters in AAS device.

\begin{tabular}{l|cccc}
\hline \multicolumn{5}{c}{ Reading parameters in AAS device } \\
\hline \multicolumn{1}{c}{ Parameters } & $\mathrm{Al}$ & $\mathrm{As}$ & $\mathrm{Cd}$ & $\mathrm{Pb}$ \\
\hline Wavelength (nm) & 309.3 & 193.7 & 228.8 & 217 \\
Slit clearance (nm) & 0.7 & 0.7 & 0.7 & 0.7 \\
Lamp Power & $25-30 \mathrm{~V}$ & $0-40 \mathrm{~V}$ & $8 \mathrm{~V}$ & $10-12 \mathrm{~V}$ \\
Linear Range (mg/lt) & 100 & 100 & 2 & 20 \\
Gas Type Used & Argon & Argon & Argon & Argon \\
\hline
\end{tabular}

Table 2. $\mathrm{Al}, \mathrm{Cd}$, and $\mathrm{Pb}$ parameters in AAS device.

\begin{tabular}{|c|c|c|c|c|c|c|}
\hline \multicolumn{7}{|c|}{$\mathrm{Al}, \mathrm{Cd}$, and $\mathrm{Pb}$ parameters in AAS device } \\
\hline Step & $\mathrm{T}\left({ }^{\circ} \mathrm{C}\right) *$ & $\mathrm{~T}\left({ }^{\circ} \mathrm{C}\right) *$ & Rise Time (s) & Retention Time $(\mathrm{s})^{*}$ & Retention Time $(\mathrm{s})^{* * *}$ & Argon Flow (ml/min) \\
\hline Dehumidification & 100 & 100 & 5 & 15 & 25 & 250 \\
\hline Drying & 140 & 140 & 10 & 25 & 30 & 250 \\
\hline Incineration & 850 & 350 & 150 & 35 & 25 & 250 \\
\hline Atomization & 1650 & 1650 & 0 & 1 & 4 & 0 \\
\hline Cleaning & 2600 & 2400 & 1 & 2 & 2 & 250 \\
\hline
\end{tabular}

* For $\mathrm{Al}$ and $\mathrm{Pb}$; ** For Cd, T:Temperature.

Table 3. Comparison of heavy metal levels of organic and conventional dairy products.

\begin{tabular}{|c|c|c|c|c|}
\hline \multicolumn{5}{|c|}{ Heavy metal levels of organic and conventional dairy products } \\
\hline & & Heavy & tals & \\
\hline Groups & $\begin{array}{l}\mathrm{Al}(\mathrm{ppm}) \text { Median } \\
(\text { min - max })\end{array}$ & $\begin{array}{l}\text { As (ppm) Median } \\
\quad(\min -\max )\end{array}$ & $\begin{array}{l}\text { Cd (ppm) Median } \\
(\text { min - max })\end{array}$ & $\begin{array}{l}\mathrm{Pb}(\mathrm{ppm}) \text { Median } \\
(\min -\max )\end{array}$ \\
\hline $\begin{array}{l}\text { Conventional } \\
\text { Milk } \\
(\mathrm{n}: 12)\end{array}$ & $\begin{array}{c}0.233 \\
\mathrm{n}: 1 \\
\mathrm{n}: 11<\mathrm{LOD}\end{array}$ & $\begin{array}{c}0.002 \\
(0.001-0.003) \mathrm{n}: 2 \\
\mathrm{n}: 10<\mathrm{LOD}\end{array}$ & $\begin{array}{c}0.088 \\
\mathrm{n}: 1 \\
\mathrm{n}: 11<\mathrm{LOD}\end{array}$ & $\begin{array}{c}0.0055^{*} \\
(0.001-0.01) \\
\mathrm{n}: 6 \\
\mathrm{n}: 6<\mathrm{LOD}\end{array}$ \\
\hline $\begin{array}{l}\text { Organic } \\
\text { Milk } \\
(\mathrm{n}: 12)\end{array}$ & $\begin{array}{c}0.726 \\
n: 1 \\
n: 11<\text { LOD }\end{array}$ & $\begin{array}{c}0.226 \\
n: 1 \\
\mathrm{n}: 11<\mathrm{LOD}\end{array}$ & $\begin{array}{c}0.003 \\
n: 1 \\
\mathrm{n}: 11<\mathrm{LOD}\end{array}$ & $\begin{array}{c}0.001^{*} \\
(0.001-0.009) \\
\text { n: } 3 \\
\text { n: } 9<\text { LOD }\end{array}$ \\
\hline $\begin{array}{l}\text { Conventional } \\
\text { White Cheese } \\
(\mathrm{n}: 12)\end{array}$ & $\begin{array}{c}0.9865 \\
(0.348-8.725) \mathrm{n}: 4 \\
\mathrm{n}: 8<\text { LOD }\end{array}$ & $\begin{array}{c}0.57 \\
(0.01-0.839) \\
\mathrm{n}: 3 \\
\mathrm{n}: 9<\mathrm{LOD}\end{array}$ & $\begin{array}{c}0.449 \\
(0.034-0.898) \\
\text { n: } 4 \\
\text { n: } 8<\text { LOD }\end{array}$ & $\begin{array}{c}0.032^{*} \\
(0.002-0.053) \\
\mathrm{n}: 6 \\
\mathrm{n}: 6<\mathrm{LOD} \\
\end{array}$ \\
\hline $\begin{array}{l}\text { Organic } \\
\text { White Cheese } \\
(\mathrm{n}: 12)\end{array}$ & $\begin{array}{c}2.281 \\
n: 1 \\
\mathrm{n}: 11<\mathrm{LOD}\end{array}$ & $\begin{array}{c}\text { LOD } \\
\mathrm{n}: 12<\mathrm{LOD}\end{array}$ & $\begin{array}{c}\text { LOD } \\
\mathrm{n}: 12<\mathrm{LOD}\end{array}$ & $\begin{array}{c}0.008^{*} \\
(0.003-0.084) \\
\mathrm{n}: 7 \\
\mathrm{n}: 5<\mathrm{LOD}\end{array}$ \\
\hline $\begin{array}{l}\text { Conventional } \\
\text { Butter } \\
(\mathrm{n}: 12)\end{array}$ & $\begin{array}{c}1.287 \\
n: 1 \\
\mathrm{n}: 11<\mathrm{LOD}\end{array}$ & $\begin{array}{c}\text { LOD } \\
\mathrm{n}: 12<\mathrm{LOD}\end{array}$ & $\begin{array}{c}0.037 \\
\mathrm{n}: 1 \\
\mathrm{n}: 11<\mathrm{LOD}\end{array}$ & $\begin{array}{c}\text { LOD } \\
\mathrm{n}: 12<\mathrm{LOD}\end{array}$ \\
\hline $\begin{array}{l}\text { Organic } \\
\text { Butter } \\
(\mathrm{n}: 12)\end{array}$ & $\begin{array}{c}2.08 \\
\mathrm{n}: 1 \\
\mathrm{n}: 11<\mathrm{LOD}\end{array}$ & $\begin{array}{c}\mathrm{n}: 1 \\
\mathrm{n}: 11<\mathrm{LOD}\end{array}$ & $\begin{array}{c}0.0185 \\
(0.018-0.019) \mathrm{n}: 2 \\
\mathrm{n}: 10<\mathrm{LOD}\end{array}$ & $\begin{array}{c}0.0195 \\
(0.003-0.036) \mathrm{n}: 2 \\
\mathrm{n}: 10<\mathrm{LOD}\end{array}$ \\
\hline
\end{tabular}




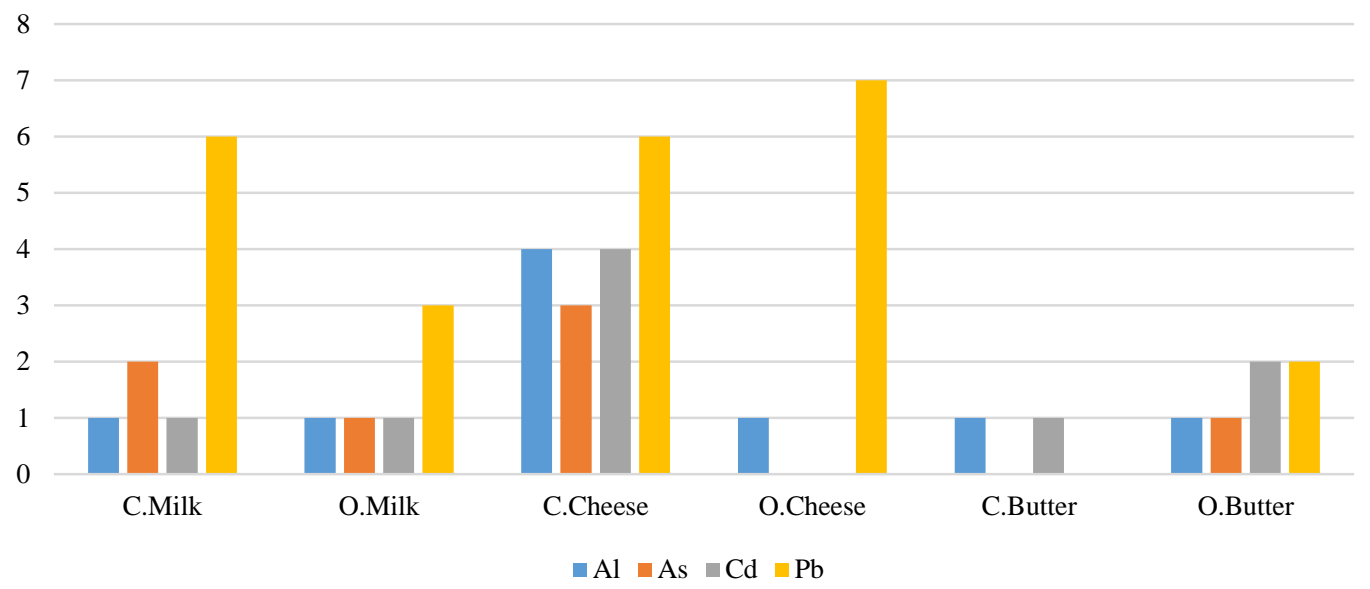

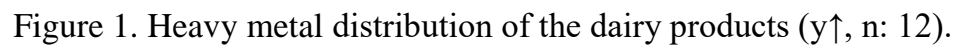

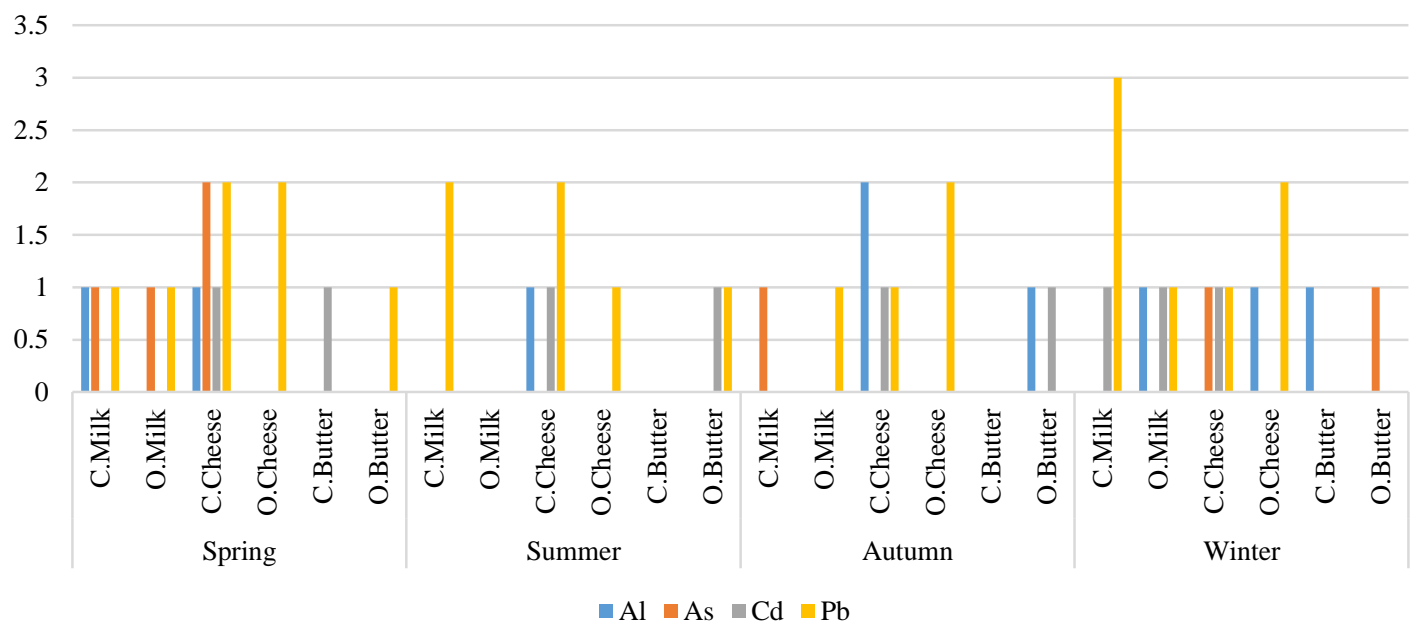

Figure 2. Heavy metal distribution of the dairy products per seasons (y个, n: 12).

The maximum estimated daily intake (MEDI) value of aluminum ( $1 \mathrm{mg} / \mathrm{kg}$ b.w./d) according to JECFA is 4.282 $\mathrm{mg} / \mathrm{kg}$ for processed cheese wrapped in Al foil (Anon, 2007; Anon, 2008). In this study, the values for cheese and butter were significantly lower than this limit and the value (5.718 mg / L or kg) -processed cheese wrapped in Al foilfound by AI-Ashmawy (2011). In a research conducted with 36 conventional milk and 40 conventional white cheese samples collected from Ankara, Turkey and neighboring districts, $\mathrm{Al}, \mathrm{Cd}, \mathrm{Pb}$, and some metal levels were measured by ICP-AES device. In the study, there was no presence of $\mathrm{Pb}$ in the samples. The mean $\mathrm{Al}$ value of milk was $6 \pm 0.57 \mathrm{ppm}$ and the mean $\mathrm{Cd}$ value was 0.114 $\pm 0.03 \mathrm{ppm}$. Meanwhile, the mean $\mathrm{Al}$ value of white cheese was $23.276 \pm 9.19 \mathrm{ppm}$ and the mean $\mathrm{Cd}$ value was 0.073 \pm 001 ppm (Temurci and Güner, 2006). Al and $\mathrm{Cd}$ values of milk and white cheese were higher than those found in this study. The fact that no $\mathrm{Pb}$ has been found can result from the difference in LOD values between methods. In another study was conducted on dairy products, heavy metal levels of total 96 samples which sold in Konya, Turkey were determined by ICP-AES. While the Al, As and $\mathrm{Pb}$ values of conventional and organic butter in this study were lower than those found by Ayar et al. (2007) (7.63 $\pm 0.96 \mathrm{ppm}, 0.146 \pm 0.59 \mathrm{ppm}, 0.116 \pm 0.21 \mathrm{ppm}) \mathrm{Cd}$ values were higher $(0.015 \pm 0.016 \mathrm{ppm})$ (Ayar et al., 2007).
In terms of elements analysis of 400 raw milk samples collected from a total of 6 regions in Aydin Province (central district and 5 districts connected to the center), they could not find detectable levels of $\mathrm{Cd}$ and $\mathrm{Pb}$ (İnci et al., 2017). In an analysis of the 140 conventional milk samples from 9 regions in Turkey with AAS, $\mathrm{Pb}$ level was found as $8.52 \pm 1.64 \mathrm{ppb}$ and $\mathrm{Cd}$ level was found as $1.09 \pm$ 0.33 ppb (Aktan et al., 1991), and they were higher than the $\mathrm{Pb}$ values found in this study for conventional milk $(0.0055 \mathrm{ppm})$ and organic milk $(0.001 \mathrm{ppm})$. In a study on organic and conventional dairy and meat products in Northern Italy, $\mathrm{Pb}$ and $\mathrm{Cd}$ residues were very low and did not differ between organic and conventional products (Gihidini et al., 2005). In a study conducted on the market milk and dairy products in Bangladesh (30 samples in total), it was observed that most of the milk samples contained copper and lead, and also copper and lead limits $(0.007 \mathrm{mg} / \mathrm{kg}-0.02 \mathrm{mg} / \mathrm{kg})$ were similar to the results of this research (Shahria et al., 2014).

When the results of this study are examined in terms of seasonal distribution (Figure 2), the high $\mathrm{Pb}$ level of dairy products may be related to indirect contamination caused by fuels (Özrenk, 2002) used for heating purposes and exhaust gases, especially in winter. As a matter of fact, in the study carried out in order to determine the seasonal (summer and winter) and change of some 
element levels of 400 milk samples according to their place of origin in Pakistan. Especially $\mathrm{Pb}$ levels $(0.455$ $\mathrm{mg} / \mathrm{kg}$ in summer; $2.0 \mathrm{mg} / \mathrm{kg}$ in winter) at the point of sale and milk obtained in winter were higher than $\mathrm{Pb}$ values of samples taken from canal edge farms $(0.227 \mathrm{mg}$ $/ \mathrm{kg}$ in summer; $1.25 \mathrm{mg} / \mathrm{kg}$ in winter) (Younus et al., 2016). Among a total of 260 conventional milk samples (130 in summer and 130 in winter) collected from Van province and its surroundings, $\mathrm{Pb}$ was found in 189 samples with the mean value of $0.002 \pm 0.01 \mathrm{ppm}(0.001$ - 0.007). It is stated that the rate of metal pollution is high in milk obtained in winter (Malmuret et al., 2002). Erdoğan et al. (2004), in a study of industrial and rural regions in the winter sampling, found the mean values of milk in rural regions as $190 \mu \mathrm{g} / \mathrm{L}$ for $\mathrm{Al}$, as $17.1 \mu \mathrm{g} / \mathrm{L}$ for As, and as $1.1 \mu \mathrm{g} / \mathrm{L}$ for $\mathrm{Cd}$. In the industrial zone, they found to be $366.2 \mu \mathrm{g} / \mathrm{L}$ for $\mathrm{Al}$, as $18.0 \mu \mathrm{g} / \mathrm{L}$ for As, and as $1.8 \mu \mathrm{g} / \mathrm{L}$ for $\mathrm{Cd}$, in milk (Erdoğan et al., 2004).

As a result of this study, 72 samples were considered safe for $\mathrm{Al}, \mathrm{As}, \mathrm{Cd}$ and $\mathrm{Pb}$ according to the Turkish Food Codex Regulation and also ADI values reported by FAO/WHO.

\section{References}

Abd-El Aal SFA, Awad EI, Kama RMKM. 2012. Prevalence of some trace and toxic elements in raw and sterilized cow's milk. Journal of American Science; 8(9): 753-761. ISSN: 1545-1003

Abd El-Gawad MAM, and Ahmed NS. 2011. Cheese yield as affected by some parameters. ACTA Scientiarum Polonorum Technologia Alimentaria; 10: 131-153.

Aktan HT, Mutluer B, Sayal A, Aydın A, Işımer, A. 1991. İnek sütlerinde kurşun ve kadmiyum miktarları üzerinde araştırma. A. Ü. Vet. Fak. Dergisi; 38 (1-2): 100-107 s.

Al-Ashmawy MA. 2011. Prevalence and public health significance of aluminum residues in milk and some dairy products. Journal of Food Science; 76(3): pT73-pT76. 4p. doi: 10.1111/j.1750-3841.2011.02064.x

Amponsah D. 2014. Determination of levels of heavy metals (arsenic, lead, cadmium and mercury) in tin milk produced in Ghana. International Journal of Advancements in Research \& Technology; 3: 129-133.

Anonymous 2007. Evaluation of certain food additives and contaminants. Sixty-Seventh Report of the Joint FAO. WHO Expert Committee on Food additives. WHO TechnicAl Report Series No. 940. WHO, Geneva.

Anonymous 2008. Codex: Aspartame, sucralose \& aluminum are still dangers. National Health Federation "NHF", Beijing The Codex Food Additives Committee Meeting. http://www.Thenhf.Com/press releases/pr28apr2008.html.

Anonymous 2011. Türk Gıda Kodeksi Bulaşanlar Yönetmeliği. T.C. Gıda, Tarım ve Hayvancılık Bakanlığı, Ankara.

Anonymous. 2016. Türkiye Beslenme Rehberi 2015 (TÜBER). T.C. Sağlık Bakanlığı, Türkiye Halk Sağlığı Kurumu, Ankara.

Arslanbaş E, Baydan E. 2013. Comparison of metal levels (lead, cadmium, cooper, zinc, iron) in certain organically and conventionally produced animal and vegetable products in Turkey. Food Additives and Contaminants: Part B: Surveillance; 6(2): 130-133.

Ayar A, Sert D, Akın N. 2007. Konya'da tüketime sunulan süt ve ürünlerinin ağır metal içeriklerinin belirlenmesi. Selçuk Üniversitesi Ziraat Fakültesi Dergisi; 21(41): 58-64.

Baydan E, Kanbur M, Arslanbaş E, Aydın FG, Gürbüz S, Tekeli FY. 2017. Contaminants in animal products. Livestock Science, Selim Sekkin, IntechOpen, doi: 10.5772/67096.
Çakır EO. 2009. Türkiye'nin farklı bölgelerinden toplanan süt örneklerinde bazı metal düzeyleri. Ankara Üniversitesi Sağlık Bilimleri Enstitüsü Doktora Tezi, Ankara.

Çiçek H, Tandoğan M. 2009. Organik süt sığırcıllı̆ında üretim maliyetleri ve karlılık açısından bir değerlendirme. Kafkas Üniversitesi Veteriner Fakültesi Dergisi; 15(1): 145-151. doi: 10.9775/kvfd.2008.22-D

Eleboudy AA, Amer AA, El-Makarem HA, Abo Hadour HH. 2017. Heavy metals residues in some dairy products. Alexandria Journal for Veterinary Sciences; 51(2): p334-346. 13p. doi: 10.5455/ajvs.230723.

Erdoğan S, Çelik S, Erdoğan Z. 2004. Comparison of selected toxic elements in cow serum and milk samples from industrial and rural regions. Bull. Environ. Contam. Toxicol.; 72: 931936.

Forman J, Silverstein J. 2012. Organic foods: health and environmental advantages and disadvantages. Pediatrics; 130: e1406-15.

Gihidini S, Zanardi E, Battaglia A, Varisco G, Ferretti E, Campanini G, Chizzolini R. 2005. Comparison of contaminant and residue levels in organic and conventional milk and meat products from Northern Italy. Food Additives and Contaminants; 22: 9-14.

Gövercin İ. 2010. İzmir İli'nde sütlerde bazı ağır metal (kurşun, kadmiyum, arsenik, civa, bakır, çinko) düzeylerinin belirlenmesi. Doktora tezi. Fen Bilimleri Enstitüsü, Ege Üniversitesi, İzmir, Türkiye.

Halagarda M, Ptasinska-Marcinkiewicz J, Fijorek K. 2018. Comparison of mineral elements content in conventional and organic milk from southern Poland. ŻYWNOŚĆ. Nauka. Technologia. Jakość; 1: 137-150.

IARC, 1993. Complete list of agents evaluated and their classification. International Agency for Research on Cancer (IARC); Erişim Adresi: http://monographs.iarc.fr/ENG/ Classification/index.php (Erişim Tarihi: 02.12.2009).

İnci A, Aypak SÜ, Güven G. 2017. Aydın ilinde üretilen inek sütlerinde bazı ağır metal düzeylerinin araştırılması. Gıda Dergisi; 42(3): 229-234. doi: 10.15237/gida.GD16079

Lawal AO, Mohammed SS, Damisa D. 2006. Assessment of levels of copper, cadmium and lead in secretion of mammary gland of cows grazed on open fields. Science World Journal; 1(1). doi: 10.4314/swj.v1i1.51689

Malmauret L, Parent-Massin D, Hardy JL, Verger P. 2002. Contaminants in organic and conventional foodstuffs in France. Food Additives and Contaminats; 19: 524-532. doi: $10.1080 / 02652030210123878$

Özrenk E. 2002. Van İli ve çevre ilçelerinde üretilen inek sütlerinin ağır metal kirlilik düzeyi ve bazı mineral madde içerikleri. Doktora tezi. Fen Bilimleri Enstitüsü, Yüzüncü Y1l Üniversitesi, Van, Türkiye.

Shahria SMS, Akther S, Akter F, Morshed S, Alam MK, Saha I, Halim MA, Hassan MM. 2014. Concentration of copper and lead in market milk and milk products of Bangladesh. International Letters of Chemistry, Physics and Astronomy; 27: 56-63.

Temurci H, Güner A. 2006. Ankara'da tüketime sunulan süt ve beyaz peynirlerde ağir metal kontaminasyonu. Atatürk Üniversitesi Veteriner Bilimleri Dergisi; 1(1-2): 20-28.

Wang M, Wang Z, Ran L, Wang Y, Yang D. 2003. Study on food contaminants monitoring in China during 2000-2001. Journal of Hygiene Research; 32(4): 322-326. PMID: 14535092

Younus M, Abbas T, Zafar M, Raza S, Khan A, Saleem AH, Idrees MA, Nisa QU, Akhtar R, Saleem G. 2016. Assessment of heavy metal contamination in raw milk for human consumption. South African Journal of Animal Science; 46 (2). ISSN 2221-4062 (online)

Ziarati P, Shirkhan F, Mostafidi M, Zahedi MT. 2018. An overview of the heavy metal contamination in milk and dairy products. Acta Scientific Pharmaceutical Sciences; 2: 08-21. 